Published as: Finnegan, J., Regan, J.T., de Eyto, E., Ryder, L., Tiernan, D., Healy, M.G. 2012. Nutrient dynamics in a peatland forest riparian buffer zone and implications for the establishment of planted saplings. Ecological Engineering 47: 155 - 164. DOI:

10.1016/j.ecoleng.2012.06.023

\title{
NUTRIENT DYNAMICS IN A PEATLAND FOREST RIPARIAN BUFFER ZONE AND IMPLICATIONS FOR THE ESTABLISHMENT OF PLANTED SAPLINGS
}

J. FINNEGAN ${ }^{\mathrm{a}}$, J.T. REGAN ${ }^{\mathrm{a}}$, E. de EYTO ${ }^{\mathrm{b}}$, E. RYDER ${ }^{\mathrm{c}}$, D. TIERNAN ${ }^{\mathrm{d}}$ and M.G.

$$
\operatorname{HEALY}^{\mathrm{a} *}
$$

${ }^{\mathrm{a} C i v i l ~ E n g i n e e r i n g, ~ N a t i o n a l ~ U n i v e r s i t y ~ o f ~ I r e l a n d, ~ C o u n t y ~ G a l w a y, ~ I r e l a n d . ~}$

${ }^{\mathrm{b}}$ Marine Institute, Newport, County Mayo, Ireland.

${ }^{\mathrm{C}}$ Centre for Freshwater Studies and Department of Applied Sciences, Dundalk Institute of Technology, Dundalk, Co. Louth, Ireland.

${ }^{\mathrm{d} C o i l l t e}$, Cedar House, Moneen Road, Castlebar, Co Mayo, Ireland.

* Tel +353 91495364 fax +353 91 494507, email mark.healy@nuigalway.ie

\section{ABSTRACT}

Forestry on peatland throughout the world is now focused on minimising destructive effects to the surrounding environment, especially during harvesting. These effects may be mitigated through the use of well-developed riparian buffers zones (RBZs). However, much of the commercial forestry planted in Ireland and the UK in the mid $20^{\text {th }}$ century was planted without adequate RBZs. The creation of new RBZs prior to clearfelling may be a possible mitigation measure in these circumstances. The aim of this paper was to assess the nutrient content and phosphorus (P) adsorption capacity of the soil, and survival of planted saplings in 
a RBZ, positioned downslope from a standing forest and partly covered with brash mats, five years after its establishment. Dissolved reactive phosphorus (DRP) concentrations were significantly higher under the brash mats in the RBZ when compared to all other areas. The standing forest had the highest concentrations of ammonium nitrogen $\left(\mathrm{NH}_{4}-\mathrm{N}\right)$, while total oxidised nitrogen (TON) was similar for all areas. Water extractable phosphorus and desorption-adsorption testing also confirmed the high concentrations of $\mathrm{P}$ under the brash mats, but P did not leach through the peat to the stream. The overall survival rate of the saplings was relatively high, with over half of Quercus robur (oak) (57 \%), Sorbus aucuparia (rowan) (57 \%) and Betula pendula (birch) (51\%) surviving. Salix cinerea (willow) (22 \%), Alnus glutinosa (alder) (25\%) and Ilex aquifolium (holly) (44\%) did not survive as successfully. The RBZ was capable of providing nutrients for the survival of planted saplings, fertilizing the peat with degrading brash material and preventing elevated levels of nutrients entering the adjacent aquatic ecosystem.

Keywords: Phosphorus, forestry, brash mats, riparian buffer zones, vegetation 


\section{Introduction}

Peatlands are found in over 175 countries worldwide, are mostly present in moist temperate climates in the northern hemisphere (Sjörs, 1980), and cover approximately $3 \%$ of the total landmass in the world $\left(4,000,000 \mathrm{~km}^{2}\right)$ (Bain et al., 2011). These ecosystems produce $10 \%$ of the global freshwater supply and one-third of the world's soil carbon content (Joosten and Clarke, 2002). Approximately 150,000 km² of this landmass has been drained for commercial forestry, while the area not commercially drained, but forested, is unknown (Joosten and Clarke, 2002). Ireland's forest cover stands at $10.15 \%$, or 700,000 ha, of the total surface area of the island (National Forest Inventory, 2007). The Irish State, under the management of the Forest Service, carried out the majority of the afforestation in the mid $20^{\text {th }}$ century. This was mainly coniferous plantation on non-productive agricultural land (Bacon, 2003). It is estimated that $59.6 \%(417,200 \mathrm{ha})$ of forestry in Ireland is on peat (National Forest Inventory, 2007) and approximately 300,000 ha of afforestation is on upland peat areas (EEA, 2004; Rodgers et al., 2010). Harvesting of forestry on peat can be challenging due to high soil water contents (gravimetric water contents usually exceed $800 \%$ (Long and Jennings, 2006)), low ground bearing capacities of between 10 and $60 \mathrm{kPa}$ (Owende et al., 2002) and the vulnerable nature of the ecosystem (Forest Research, 2009). In Ireland, forestry harvesting practice (including thinning) minimises soil disturbance by adopting appropriate mitigation measures such as: (1) the use of low ground pressure machines and (2) the laying of brash mats, consisting of small branches and logs under all paths used by the felling and extraction machinery. The scale of soil disturbance to a clearfell site is dependant on a combination of factors, 
including the number of passes by machinery, soil water content and the effective use of brash mats (Gerasimov and Katarov, 2010).

Forestry on peatland throughout the world is now moving towards a 'progressive management approach' (Joosten and Clarke, 2002), which incorporates sustainable timber production alongside multiple uses such as habitat restoration, ecological regeneration and the minimisation of any potentially negative effects to the surrounding environment. These negative effects may include eutrophication (an increase in nutrient levels in a watercourse causing excessive flora growth (Sharpley et al., 2003)), sedimentation (an increase in suspended sediment (SS) release to a watercourse causing damage to water ecology (Rodgers et al., 2011)) and biodiversity loss (a change of species, genetic and ecosystem diversity (Walker, 1992)). Coillte, the Irish State's current forest management company, is certified under the Forest Stewardship Council (FSC) to enforce strict environmental, economic and social criteria for sustainable forest management (Coillte, 2012). This progressive and sustainable management approach includes more effective planning to provide protection to water-courses from drainage, fertilisation and afforestation, final harvest and regeneration (Owende et al., 2002). Some of this protection may be provided by riparian buffer zones (RBZs).

The standard forestry practice in Ireland and the UK at the time of afforestation (in the 1950s) led to trees being planted in areas adjacent to water-courses with no allowance for a RBZ (Broadmeadow and Nisbet, 2004; Ryder et al., 2011). This lack of a buffer may result in elevated nutrient and SS release into water-courses during clearfelling 
(Carling et al., 2001). Other negative effects in the absence of RBZs are the excessive quantity of shade to the stream provided by the overhanging mature conifer plantations, which leads to a death of the riparian vegetation and leaves the bank sides susceptible to erosion (Broadmeadow and Nisbet, 2004). The presence of commercial conifers close to the edge of a stream is also likely to affect the emergence of invertebrates and the biodiversity in comparison to deciduous trees (Broadmeadow and Nisbet, 2004; Kominoski et al., 2012). Much of the commercial coniferous forestry planted in the 1950s is now at harvesting age and the adoption of current forest practice which creates RBZs will minimise the risk of negative impacts on receiving waters for successive rotation.

Riparian buffer zones are used in forestry worldwide in areas such as Fennoscandia (Syversen and Borch, 2005; Väänänen et al., 2008), the USA and Canada (Aust and Blinn, 2004; Luke et al., 2007), and in New Zealand (Parkyn et al., 2005), to ameliorate the negative impacts of forestry on adjacent water-courses. In the UK, forestry planning since the 1990s has allowed for RBZs of native hardwoods to provide shade and shelter for wildlife and the stream inhabitants, and for existing conifer streamside plantations to be felled and restored (Farmer and Nisbet, 2004). Current forest practice in Ireland incorporates the use of buffer zones along waterways, with widths of between $10 \mathrm{~m}$ and $25 \mathrm{~m}$ depending on slope and soil erodibility (Forest Service, 2000). However, RBZs need to be created in old forest stands on peat soil in the most sustainable method possible.

A RBZ can be created in two ways: (1) by leaving an intact strip of forest adjacent to the stream and clearfelling the main coupe of trees behind it, or (2) by harvesting the 
trees from a strip beside the stream a number of years prior to clearfelling the main coupe and allowing the area to revegetate, either naturally or artificially (Ryder et al., 2011). Forest buffer zones (option one, with trees left in buffer zone) in the UK have been shown to be successful at allowing sedimentation to occur within the buffer because of a slowing down of the surface runoff due to the well-structured and normally drier character of forest soils (Broadmeadow and Nisbet, 2004) and the increased macroposity from tree roots and soil fauna (Goudie, 2006). This is coupled with the damming effect created by falling debris and protruding roots in the forest buffer, which form sediment traps (Broadmeadow and Nisbet, 2004). However, this option may not be practical in the west of Ireland due to thin soil depths, exposed sites and high winds, leading to the increased chance of wind throw close to the watercourse, resulting in a higher risk of sedimentation and nutrient runoff. The second RBZ creation option has potential to be adopted in Ireland, as it increases the primary production in the stream, provides adequate shade and leaf litter, promotes greater biodiversity and taxon richness, and increases sunlight to the watercourse (Ryder et al., 2011). Ground vegetation is also an important method of slowing down flow and trapping sediment (Broadmeadow and Nisbet, 2004). It has been noted, however, that there can be a significant time delay in establishing ground vegetation on sites on which the logging residues have been left (Broadmeadow and Nisbet, 2004). Ormerod et al. (1993) conducted a study on 11 upland streams in forestry catchments that had been clearfelled from one to seven years prior to their study and noted that the streams had retained some of the characteristics of a forestry catchment stream, even after 7 years of recovery. Ryder et al. (2011) found that the creation of RBZs resulted in increased water discharge and significantly higher SS loads to receiving waters, an 
elevated stream temperature, and minor changes in the average abundances and taxon richness of macroinvertebrate communities. These effects were consistent with the short-term negative impacts of felling at the time of creation of the RBZs. Nevertheless, the creation of RBZs in this way was not felt to have catastrophic effects on the receiving water course and its inhabitants, and any impacts were short-lived (Ryder et al, 2011).

Coillte’s District Strategic Plan 2011 - 2015 specifies a 20 m unplanted strip followed by $10-20 \mathrm{~m}$ of broadleaf plantation between a permanent water-course and conifer forest (Coillte, 2011). This would result in the production of scrub broadleaf cover with a protective function only (Coillte, 2011). The tree species planted in a RBZ are generally recommended to be the native variety and species choice will have an impact on the efficiency of the buffer (Broadmeadow and Nisbet, 2004). Factors such as shade and canopy density need to be taken into consideration, as RBZs are seen to function more efficiently when there is a high level of ground covering plants (Broadmeadow and Nisbet, 2004). Dense planting of species with larger leaf areas, like Alnus (alder) or Quercus (oak), may provide too much shade for the successful growth of the lower ground covering plants and it is recommended that they are not planted in large groups, but rather dispersed throughout the RBZ with species with lower canopy density such as Salix (willow), Betula (birch) and Sorbus (rowan) (Broadmeadow and Nisbet, 2004). Alder is also suspected of adding to stream acidification due to its ability to fix nitrogen $(\mathrm{N})$ from the atmosphere and, therefore, should be limited in RBZ regeneration projects (Broadmeadow and Nisbet, 2004). It is relatively unknown which 
(if any) native deciduous species are likely to survive, if planted in upland peats following clearfelling of coniferous forest.

Due to the upland nature of these areas, many of these catchments include headwater streams, which are important salmonid habitats and need to be protected from nutrient enrichment. The phosphorus (P) retention capacity of a soil is partly dependant on its abundance of aluminium (Al) and iron (Fe) compounds (Giesler et al., 2005; Väänänen et al., 2006). Aluminium and Fe are readily available in mineral soil, but are lacking in peat. However, as the mineral layers, where they occur, in riparian peatland buffers aid in retaining higher quantities of $\mathrm{P}$ than peat further back from the riparian zone (Väänänen et al., 2006), one option to mitigate P loss from peat forests to receiving waters is to create RBZs in existing forest stands prior to clearfelling the main coupe behind the buffer zone (Ryder et al., 2011). Desorption-adsorption isotherms can indicate the amount of P retained in the soil and show the adsorption properties of the soil, while water extractable phosphorus (WEP) testing measures the readily available fraction of the soil $\mathrm{P}$ and is used as an indicator of the amount of $\mathrm{P}$ that may be carried from a soil by surface runoff in storm events. Current recommended buffer widths in Ireland of $10-25 \mathrm{~m}$ may not be capable of removing all nutrients from the runoff during high storm events when the majority of the $\mathrm{P}$ is transported, as the retention time may be too short for uptake of soluble P by vegetation (Rodgers et al., 2010). It has been shown that elevated levels of nutrients and sediment are frequently associated with clearfelling operations for up to 4 years (Cummins and Farrell, 2003; Rodgers et al., 2010; Rodgers et al., 2011). Although P can become fixed in the soil and only a small amount may be leached to water-courses (Haygarth et al., 1998), even small 
concentrations (> $35 \mu \mathrm{g} \mathrm{L^{-1 }}$ molydbate reactive phosphorus (MRP)) can have a negative impact on water quality (Bowman, 2009), leading to restrictions of use for fisheries, recreation, industry and drinking water (Elrashidi, 2011; Sharpley et al., 2003). Phosphorus can be found in both dissolved and sediment-bound (minerals and organic matter) forms. Dissolved P is bio-available and is therefore the main cause of eutrophication in freshwater (Elrashidi., 2011; Regan et al., 2010; Sharpley et al., 2003; Väänänen et al., 2006). In Ireland, P is the limiting nutrient for eutrophication (Hutton et al., 2008) and is therefore the nutrient of greatest interest. The limit for MRP, which is similar to dissolved reactive phosphorus (DRP) (Haygarth et al., 1997), concentrations in Irish rivers to maintain 'good ecological status' is $35 \mu \mathrm{g} \mathrm{L} \mathrm{L}^{-1}$ and for 'high ecological status' is $25 \mu \mathrm{g} \mathrm{L} \mathrm{L}^{-1}$ (Bowman, 2009). A conservative value of $30 \mu \mathrm{g} \mathrm{L}$ ${ }^{1}$ has been statistically linked with lower biological Q ratings (biological quality ratings) (EPA, 2005), phytoplankton production (Daniel et al., 1998) and increased algal growth in freshwaters (Haygarth et al., 2005).

The aim of this study was to examine the characteristics of an uncultivated RBZ, in an upland peat area in the west of Ireland. The RBZ was clearfelled 5 yr previous to the present study and restocked 1 yr later with group planted broadleaf species. Specifically, the following characteristics were examined in the 5 yr old RBZ: (1) the deciduous species of trees which were able to survive and thrive (2) the soil and surface water nutrient content, and (3) the $\mathrm{P}$ adsorbing capacity of the soil in the regenerated zone and in the standing forest. This allowed for an assessment of the function and performance of RBZs to supply nutrients to various native species of 
growing saplings within peatland forestry, and to provide some protection against nutrient export into receiving waters.

\section{Materials and Methods}

\subsection{Study Site Description}

The study site was located in the Altaconey (also known as Altahoney) forest in the Burrishoole catchment in Co. Mayo, Ireland (ITM reference 495380, 809170) (Figure 1). This catchment is situated in the Nephin Beg range at an approximate elevation of $135 \mathrm{~m}$ above sea level. The study stream is a third-order stream (Strahler, 1957) and is located within a subcatchment area of 416.2 ha, of which 176.4 ha is fully forested (Ryder et al., 2011). The site has a north-westerly aspect, while the study stream, which is one of the main tributaries to the Altaconey River, flows in a southwest-tonortheast direction to the north of the site before turning south to join the Altaconey River. There is a moderate climate, which is heavily influenced by the proximity of the Atlantic Ocean, with average air temperatures of $13{ }^{\circ} \mathrm{C}$ in summer and $4{ }^{\circ} \mathrm{C}$ in winter. The site is subjected to approximately $2400 \mathrm{~mm}$ of rainfall every year, with 289 rain days between May 2010 and April 2011. As a result, the area is characterised by upland spate streams and gorged drains. The Altaconey river responds quickly to rainfall events, and discharge frequency curves are characterised by steep amplitudes and extremely fast falling crests, with $75 \%$ of the total runoff in the Altaconey river originating from direct runoff (Muller, 2000). Upland spate streams are very characteristic of peat catchments in the west of Ireland, particularly within the 
Burrishoole catchment (Allott et al., 2005). The average slope across the buffer zone is $5 \%$ and this increases to $35 \%$ within $10 \mathrm{~m}$ of the stream, while the slope down the stream bed is approximately $2.5 \%$. The stream bed consists of boulders and gravel, while mineral-rich peat is evident along the banks and slopes adjacent to the watercourse. Blanket peat of varying depth down to $2 \mathrm{~m}$ covers the site, which overlays a sand and gravel layer on top of the Cullydoo formation of Srahmore quartzite and schist bedrock (McConnell and Gatley, 2006). This blanket peat is an insitu blanket mire with an average gravimetric water content of greater than $85 \%$, dry bulk density of approximately $0.1 \mathrm{~g} \mathrm{~cm}^{-3}$ and a mineral content of approximately $3 \%$. Bedrock does not protrude the surface of peat and the minimum peat depth is $0.3 \mathrm{~m}$. Closer to the stream, the mineral-rich peat is at a shallower depth of less than $1 \mathrm{~m}$, has an average gravimetric water content of $35 \%$, a dry bulk density of approximately $1 \mathrm{~g}$ $\mathrm{cm}^{-3}$, and a mineral content of approximately $95 \%$. During the course of the study, the RBZ had a yearly average water table depth of $0.17 \mathrm{~m}$, while the average water table depth in the standing forest was $0.42 \mathrm{~m}$.

The site was planted in 1966 with Sitka Spruce (Picea sitchensis) and Lodgepole Pine (Pinus contorta). In May 2006, an area of 2.49 ha $30 \mathrm{~m}$ north, $50 \mathrm{~m}$ south and $300 \mathrm{~m}$ along the stream was clearfelled to create the RBZ (Ryder et al., 2011) (Figure 1). This is wider than the current buffer width recommendation of $10-25 \mathrm{~m}$. In line with best management practice (BMP), brash mats were used to prevent soil damage by the heavy logging machinery. These mats were created by the harvester, which laid the logging residues of branches and un-merchantable logs in front of the harvester in continuous, slope-dependant strips on which it travelled as it felled the trees. These 
were left in situ on completion of clearfelling. Typical forest practice would normally be to windrow these brash mats into regular rows away from the watercourse when preparing the site for replanting. The direction and position of the brash mats on the southern side of the RBZ are shown in Figure 1. No rutting due to brash mat use was noted on site.

In April 2007, one year after felling, the area was replanted with native broadleaved tree species from Coillte nurseries, including Ilex aquifolium (holly), Sorbus aucuparia (rowan), Alnus glutinosa (common alder), Salix cinerea (grey willow), Betula pendula (common birch) and Quercus robur (oak pedunculate). These saplings were all containerised and of varying height ranges: (1) $0.4-0.8 \mathrm{~m}$ (birch, rowan and willow) (2) 0.3 - $0.5 \mathrm{~m}$ (oak and alder) (3) $0.1-0.2 \mathrm{~m}$ (holly). All saplings were $2 \mathrm{yr}$ old, except the birch, which was 3 yr old. No fertilizer was applied and the area was not cultivated, but the saplings were pre-treated by dipping in Dimethoate (pyrethroid insecticide) to protect them against the pine weevil (Hylobus abietis) (Ryder et al., 2011). This planting was not intended to be productive commercial forestry (expected survival rates of $>90 \%$ after $4 \mathrm{yr}$ ), but aimed to examine which species of trees had the potential to establish and survive in a hostile peatland environment. The perimeter of the created buffer zone was then fenced off to protect it from grazing by sheep and wild animals, not including deer, as a sufficiently high (exceeding $2.1 \mathrm{~m}$ ) fence was not installed.

\subsection{Vegetation}


A detailed description of the location and composition of the sapling planting regime in April 2007, post clearfelling, was conducted by Ryder et al. (2011) (Table 1). Thirty-three plots in total, 20 on the southern side and 13 on the northern side of the stream, were planted in a $2 \times 2 \mathrm{~m}$ block pattern with a red stake placed in the centre of the plot for identification (Figure 2). Nine trees per plot were planted, totalling 297 saplings of various tree species across the site (birch, alder, rowan, willow, holly and oak). No planting took place within $5 \mathrm{~m}$ of the stream. In August 2011, as part of the present study, a survey was carried out to determine the percentage survival and increase in height of the surviving saplings. An increase in height was measured as the percentage change from the average original height (obtained from Coillte Nurseries, pers. comm.) to the measured height on site in August 2011. For example, no change in height was denoted as a $0 \%$ change, while an increase in height from $0.4 \mathrm{~m}$ to $1 \mathrm{~m}$ (a change in height of $0.6 \mathrm{~m}$ ) was given a $150 \%$ increase.

\subsection{Water Analysis}

Subsurface and surface water samples were collected throughout the site and upstream and downstream of the buffer (Figure 1), mainly during high peak or storm events from April 2010 to April 2011 ( $\mathrm{n}=5$ dates) to examine the movement and concentration of nutrients in the peat and surface runoff. Sampling was focused on the RBZ, but also included the adjacent mature standing forest to allow comparison with the original condition of the buffer prior to clearfelling in 2006. All samples were grouped under four specific locations: (1) $1 \mathrm{~m}$ from the stream (within the RBZ) (2) under brash mats (within the RBZ) (3) under the vegetated areas (within the RBZ but 
not under brash mats) and (4) the standing forest. The standing forest to the left of the RBZ (in Figure 1) is at the same topographical location as the RBZ, has a similar slope and peat depth, and has similar mineral-rich peat near the stream. The direction of groundwater flow on site was perpendicular to the stream and the brash mats. Therefore, any vegetated areas within the RBZ, which had no brash directly on them, were still influenced by the decaying brash material.

Standpipes were installed on site for subsurface water quality measurement and their locations are illustrated in Figure 1. Each sampling location comprised a cluster of 3 sampling tubes positioned at $20 \mathrm{~cm}, 50 \mathrm{~cm}$, and $100 \mathrm{~cm}$ depths below the soil surface. Each standpipe consisted of a qualpex pipe with an internal diameter of $1.1 \mathrm{~cm}$. Holes were drilled in the lower $10 \mathrm{~cm}$ of the pipe and this was covered with gauze. A steel rod was inserted into the pipe for support, as it was hand-pushed into the peat. The top of the standpipes were covered to prevent the ingress of rain water. Any water lodged in the bottom of the standpipe was removed under suction the day before water sampling and the standpipe was allowed to fill overnight. Once extracted from the pipe, water samples were filtered on site using $0.45 \mu \mathrm{m}$ filters.

All water samples were returned to the laboratory and tested the following day or frozen for testing at a later date. The water quality parameters measured were: (1) DRP (2) ammonium- $\mathrm{N}\left(\mathrm{NH}_{4}-\mathrm{N}\right)$ (3) nitrate- $\mathrm{N}\left(\mathrm{NO}_{3}-\mathrm{N}\right)$ and (4) total oxidised nitrogen (TON; $\mathrm{NO}_{3}-\mathrm{N}+$ nitrite-N $\left.\left(\mathrm{NO}_{2}-\mathrm{N}\right)\right)$. All water samples were tested in accordance with standard methods (APHA, 1998) using a nutrient analyser (Konelab 20; Thermo Clinical Labsystems, Finland). Nutrient data were $\log _{10}$ transformed and analysed with 
ANOVA (analysis of variance) in Datadesk (Data Description Inc., USA), to ascertain the main sources of variation. Date, depth of soil where the sample was taken and the location of the sample site were included as explanatory variables.

Inverse distance weighted (IDW) analysis was carried out on the study area using ArcGIS (Release Version 9.3, Environmental Systems Research Institute (ERSI), California, USA) to show the concentrations of nutrients under the decaying brash mats. Inverse distance weighted analysis is a geospatial analytical tool which interpolates between sampling points, giving a greater weight to values closest to the cell value being interpolated. A 'halo' effect on individual standpipes can be caused where very high concentrations are in close proximity to lower concentrations, giving a shorter distance for interpolation between the points.

\subsection{Soil Analysis}

Water extractable phosphorus and desorption-adsorption isotherm testing were carried out on samples of the soil from the RBZ and the adjacent mature standing forest. For both tests, a series of sampling points were selected in three transects parallel to the stream in the RBZ at the following locations: (1) $1 \mathrm{~m}$ from the stream (n=10) (2) under the brash mat approximately $35 \mathrm{~m}$ from the stream ( $\mathrm{n}=20)$, and (3) under a vegetated area in-between brash mats approximately $45 \mathrm{~m}$ from the stream $(\mathrm{n}=20)$. Soil samples $(n=10)$ were also collected from the mature standing forest to represent the contributing area. To select the sampling locations, a grid was laid out on the standing forest, and soil samples were extracted at random locations on the grid. Samples were 
extracted with a $30 \mathrm{~mm}$-diameter gouge auger after clearing of the Oi horizon, litter layer, which was mainly composed of degrading moss and needles. Väänänen et al. (2007) found that this layer had the lowest P retention capacity and it was therefore omitted from testing in the present study. Samples were then placed in sealed bags on site and were homogenized by hand in the laboratory.

For WEP tests, samples were collected in spring 2011 at two depths, $0-0.1 \mathrm{~m}$ and 0.1 $-0.5 \mathrm{~m}$, along each transect. Sub-samples of peat ( $\mathrm{n}=5$ from each depth), equivalent to $1 \mathrm{~g}$ dry weight, were mixed with $30 \mathrm{ml}$ of deionized water and shaken for $30 \mathrm{~min}$ at $225 \mathrm{rpm}$ using a rotary shaker after Rodgers et al. (2010). The filtered supernatant water (filtered with $0.45 \mu \mathrm{m}$ filters) was tested using a nutrient analyser (Konelab 20; Thermo Clinical Labsystems, Finland). The remaining soil sample was used to determine the gravimetric water contents.

For desorption-adsorption isotherm testing, the soil samples were collected at depth increments of $0-0.15 \mathrm{~m}$ and $0.15-0.30 \mathrm{~m}$ below the soil surface. Phosphorus solutions were made up to concentrations of $0,0.2,0.5,1,2,3.5$ and $10 \mathrm{mg} \mathrm{P} \mathrm{L}^{-1}$. Subsamples of peat ( $\mathrm{n}=3$ for each depth and each concentration), equivalent to $1 \mathrm{~g}$ dry weight, were mixed with $40 \mathrm{ml}$ of the P solution and shaken for $1 \mathrm{hr}$ at $180 \mathrm{rpm}$ using a rotary shaker. The $10 \mathrm{mg} \mathrm{P} \mathrm{L}^{-1}$ solution was only used for the samples collected $1 \mathrm{~m}$ from the stream due to the high mineral content. The solutions were then allowed to stand for $23 \mathrm{hr}$ before being placed in the shaker again for 5 min at $120 \mathrm{rpm}$ after Väänänen et al. (2008). The filtered $(0.45 \mu \mathrm{m})$ supernatant water was tested using a nutrient analyser (Konelab 20; Thermo Clinical Labsystems, Finland). The remaining 
soil sample was used to determine the gravimetric water contents and the mineral content, which was determined by loss on ignition (LOI) at $550{ }^{\circ} \mathrm{C}$ (BSI, 1990).

\section{Results and Discussion}

\subsection{Vegetation}

The overall survival rate of the planted saplings by 2011 was relatively high, given that the site was not cultivated, no fertiliser was applied and broadleaves were planted in an environment hostile for their survival. Over half of oak (57\%), rowan (57\%) and birch (51\%) saplings survived, suggesting that adequate nutrients were available in the RBZ. However, the survival of willow (22 \%), alder (25\%) and holly (44\%) was not as successful, but evidence of surviving saplings was found in some plots. For saplings of an original height and nature similar to that of this study, some degree of protection and care should be afforded to ensure growth (M. Sheehy Skeffington, pers. comm.) and vegetation control is vital for a plant to thrive (Renou-Wilson et al., 2008). However, maintenance and grass removal is generally not performed on saplings planted in peat areas. The study area was fenced off to protect the saplings from grazing (except deer who could possibly jump the fence), but grass and other shading species were not removed from around the saplings. Sphagnum spp., Erica spp. and Calluna spp had naturally regenerated in the RBZ, and were likely to be competing aggressively with the planted saplings for both nutrients and light. It is not known if naturally regenerated ground vegetation alone would suffice for excessive nutrient uptake if the native saplings were not planted in the RBZ. Further research should be 
carried out to quantify the need for broadleaf plantation on clearfelled RBZs for nutrient uptake.

Figure 3 shows the percentage increase in the height of the surviving saplings from the various tree species. Even though $57 \%$ of oak survived after 5 yr on site, there was very little growth in the saplings (26\%). In comparison, the $51 \%$ of birch that survived had a percentage increase in height of $70 \%$. Similarly, Renou-Willson (2008) found that oak seedlings only grew $13.9 \mathrm{~cm}$ in $3 \mathrm{yr}$ where mounding was employed on a cutaway peatland in the Irish midlands, whereas native birch was reported to grow up to $50 \mathrm{~cm}$ per year in the same location (Renou et al., 2007). In the present study, Calluna vulgaris was very evident on the site and was close to the oak plots; this may have negatively impacted on the survival and growth of oak. Frost et al. (1997) noted that competition from grass turf led to a significant increase in the seedling mortality of oak species such as Quercus robur and observed that C. vulgaris had a negative impact on the growth of seedlings of $Q$. petraea due to the hindering of the mycorrhiza development (the mutually beneficial relationship between the fungus and the roots of the plant). Rowan had the greatest increase in height over all other species, with a growth of $73 \%$ in surviving saplings. The willow that survived experienced no growth over the study period ( 0 \%) with the majority of the plants barely progressing beyond seedling stage. Of the 12 alder plants that were originally planted, 3 survived, and only one of these 3 surviving plants experienced growth during the 5 yr study period. Holly, at approximately $0.15 \mathrm{~m}$, was the smallest in size to be originally planted and the surviving holly saplings (44 \%) saw an overall growth of $22 \%$. 
In the west of Ireland, natural broadleaf regeneration is rare and is largely limited to river banks of higher mineral content than the surrounding infertile peatland (Conaghan, 2007, unpublished report). No planting took place within $5 \mathrm{~m}$ of the stream, but it was noted that there was a number of large trees ( $>2 \mathrm{~m}$ high) of various species (oak, rowan and holly) on the banks of the stream, which were not planted during the saplings' planting regime in 2007. Conaghan (2007, unpublished report) observed that growth of broadleaved trees is more successful in previously forested areas with a peat depth of less than $1 \mathrm{~m}$, and also noted that sites with better drainage and shelter fostered a better environment for the growth and survival of transplants. The exposed nature of the Altaconey site and the depth of peat may have adversely affected the growth rate of the willow, alder and holly species. Conaghan (2007, unpublished report) also observed that the survival of willow cuttings placed directly into the peat was low, but larger willow transplants, which were grown for a time prior to transplanting in more fertile soil, did thrive. In the present study, the height of the willow saplings planted in April 2007 was approximately $60 \mathrm{~cm}$, but this did not appear to survive (22\%) or grow (0 \%) very well. Overall, the survival rate of the planted saplings was relatively high, taking into consideration the lack of cultivation, artificial fertilisation and maintenance, possibly grazing by deer and late planting of the saplings. A greater growth rate may have been obtained if any of these management techniques had been employed in the early stages of establishment.

\subsection{Water Analysis}


Date and depth were not significant sources of variation for any of the nutrient data, while the location of the sampling site was significant for both DRP and $\mathrm{NH}_{4}-\mathrm{N}$ (ANOVA, $p<0.05$ ). Dissolved reactive phosphorus was significantly higher under brash in the RBZ and was significantly lower close to the river $(\mathrm{p}<0.05$, LSD post-hoc test) (Figure 8). Ammonium-nitrogen in the standing forest was significantly higher than that recorded under brash or in the vegetated parts of the RBZ $(\mathrm{p}<0.05$, LSD posthoc test). Levels of TON were generally similar across all locations sampled (Figure 8). Surface and subsurface concentrations of $\mathrm{NO}_{3}-\mathrm{N}$ were all low and were, in many cases, below the limits of detection with a maximum concentration of $20 \mu \mathrm{g} \mathrm{L}^{-1}$ (results not shown).

Inverse Distance Weighted images, generated from the subsurface DRP concentrations, show the comparison of the RBZ with the standing forest (Figure 4). This illustrates the higher nutrient concentration under the decaying brash mats in the RBZ, which were left on site 5 yr before the present study. The DRP concentration reduced close to the stream edge due to the adsorption capacity of the mineral-rich peat near the stream (discussed in Section 4.3). The high concentrations of DRP in the subsurface water under the brash mats and surrounding areas did not leach to the stream, as frequent analysis of stream water upstream and downstream of the buffer showed that it remained at between $4-10 \mu \mathrm{g} \mathrm{L}-1$ (Figure 5). These values represent no change from buffer creation (May 2006 - January 2007) (Ryder et al., unpublished report), when MRP concentrations were approximately $5 \mu \mathrm{g} \mathrm{L}^{-1}$ in the stream. This is similar to the concentration in the rain water in the area, which was approximately 6 
$\mu \mathrm{g} \mathrm{L}^{-1}$ (data not shown; figure based on 5 random rain samples analysed by the authors over the study period).

Brash mats were created on site during clearfelling to protect the peat from consolidation due to heavy machinery. Since creation of the RBZ in May 2006, 5 yr prior to the present study, the peat was fertilised by these brash mats, as seen in Figure 4, and may easily have been removed from site for commercial purposes (Forest Research, 2009). However, peat is considered highly vulnerable to a loss in fertility and the removal of brash material from site can deplete the amount of base cations and reduce available nutrients for the future growth of trees (Forest Research, 2009). The potential loss of nutrients may be minimised through careful timing of brash removal after the needles have fallen. Needles contain half-to-two thirds of total nutrients of the brash material and the needle drop time period may occur anywhere from 3 to 9 mo following clearfelling, depending on local climate and season (Forest Research, 2009). Hyvönen et al. (2000) showed that after 6 - 8 yr of decomposition, needles and twigs provided more nutrients for future tree growth as opposed to larger branches, and the decomposition rate (and therefore nutrient addition) decreased with increasing branch diameter. It was noted by Hyvönen et al. (2000), however, that 16 yr after clearfelling, the decomposing branches increased the carbon content of the forest floor by up to 50 - $100 \%$ and woody logging residues provided more $\mathrm{N}$ and $\mathrm{P}$ release than needles. Nutrient release from decaying brash may enter sensitive receiving waters (Stevens et al., 1995), but this did not occur at the site of the present study. However, if brash was to be removed from peatland sites following fertilisation from needle drop time period, 
other factors such as sediment release and economic value of degraded brash would need to be considered.

\subsection{Soil Analysis}

The WEP was highest in the vegetated areas and under the brash mats in the RBZ (Figure 6) due to the leaching of $\mathrm{P}$ from the decaying brash mat into the soil in the $5 \mathrm{yr}$ since the creation of the buffer zone. Similar results were obtained by Rodgers et al. (2010), who found that WEP under windrows of brash was significantly higher than WEP in a windrow/brash-free area. The impact of the brash on WEP is a function of the length of time it is left on site and the time taken for regeneration of vegetation to occur (Macrea et al., 2005). The role of vegetation in nutrient uptake was investigated by O’ Driscoll et al. (2011), who measured WEP concentrations of 6-9 mg P kg-1 dry soil from a seeded plot in contrast to $27 \mathrm{mg} \mathrm{P} \mathrm{kg}^{-1}$ dry soil from an unplanted plot positioned on a recently harvested site. As the brash mats run perpendicular to the flow of water in the present study, any vegetated areas down-slope from the brash mats, but not directly overlain by brash mats, were also affected. Water extractable phosphorus decreased closer to the stream, but this reduction was due to the presence of a mineralrich peat along the bank of the stream, which protected the water-course from increases in nutrient concentration. As there is a strong correlation between WEP measured in peat and DRP concentration in surface runoff (O’ Driscoll et al., 2011), the potential for high concentrations of DRP in surface runoff from under the brash mats is high. 
521 The desorption-adsorption isotherms of $\mathrm{P}$ adsorption by weight ( $\mathrm{mg} \mathrm{g}^{-1}$ dry material)

522

523

524

525 showed that, while the $\mathrm{P}$ adsorption capacity was of the same magnitude in all areas for the $0-0.15 \mathrm{~m}$ depth examined, more $\mathrm{P}$ adsorption took place at a distance of $1 \mathrm{~m}$ from the stream at the $0.15-0.3 \mathrm{~m}$ depth (Figure 7 ). This was due to the mineral-rich peat at this location. At both depths, the peat directly underneath the brash mat appeared to be at $\mathrm{P}$ saturation and had little remaining adsorption capacity (reflecting the high DRP concentrations at these points; Figure 4). As is typical for soils with a low $\mathrm{P}$ retention capacity, the $\mathrm{P}$ adsorbed to the peat continued to rise with higher $\mathrm{P}$ solutions and a maximum adsorption value was not reached (Väänänen et al., 2007). Desorption of $\mathrm{P}$ from the peat in all areas and at both depths occurred when it was overlain with water with a $\mathrm{P}$ concentration of $0 \mathrm{mg} \mathrm{L}^{-1}$ (Figure 7). This was greatest under the brash mats and under the vegetated areas, especially at the $0-0.15 \mathrm{~m}$ depth.

When the results were expressed per volume of dry material $\left(\mathrm{mg} \mathrm{cm}^{-3}\right)$ and the bulk densities of the mineral-rich peat soil $1 \mathrm{~m}$ from the stream (approximately $1 \mathrm{~g} \mathrm{~cm}^{-3}$ ) and the peat further up the buffer (35 - $45 \mathrm{~m}$ from the stream; approximately $0.1 \mathrm{~g} \mathrm{~cm}^{-}$ ${ }^{3}$ ) were considered, the differences in the adsorption capacity of the soils was more pronounced: the $\mathrm{P}$ adsorption capacity of the mineral-rich peat $1 \mathrm{~m}$ from the stream were much higher than the peat layers further up the buffer. Loss on ignition analysis showed that there was 90 - $95 \%$ mineral content in the samples $1 \mathrm{~m}$ from the stream, while the samples further back from the stream $(35-45 \mathrm{~m})$ had a $98-100 \%$ organic content. This trend was similar to what was found by Väänänen et al. (2006) in their study on peat and mineral soils in Finland. 
1. The created RBZ was capable of providing nutrients to planted saplings, fertilizing the peat with degrading brash material and preventing elevated levels of nutrients entering the adjacent water-course. This indicates that a created $\mathrm{RBZ}$ is a realistic management option in peatland forests.

2. The overall survival rate of the planted saplings in the RBZ was relatively high, with over half of oak, rowan and birch saplings surviving after 5 yr. The survival of willow, alder and holly was not as successful, possibly due to a number of factors including the exposed nature of the site, peat depth, maintenance, cultivation and fertilization.

3. Dissolved reactive phosphorus concentrations were significantly higher under the brash mats in the RBZ compared to all other areas. These high concentrations of DRP were due to the degrading brash mats left on site following clearfelling. However, this did not leach to the stream as the concentration of DRP upstream and downstream of the buffer remained low throughout the study. The standing forest had the highest concentrations of $\mathrm{NH}_{4}-\mathrm{N}$, while TON was similar for all areas. It is recommended to leave brash mats on site following clearfelling to fertilise the site and to reduce disturbance to the vulnerable peat sites.

4. Water extractable phosphorus and desorption-adsorption testing also confirmed the high concentrations of $\mathrm{P}$ under the brash mats. Water extractable phosphorus was highest in the vegetated areas and under the brash mats in the 
579

580

581

582

583

584

585

586

587

588

589

590

591

RBZ. Desorption of $\mathrm{P}$ was highest under the brash mats and adsorption was greatest in the mineral-rich peat soil adjacent to the stream.

\section{Acknowledgements}

This work was funded by the Department of Agriculture, Fisheries and Food and the Environmental Protection Agency under the STRIVE program 2007 - 2013. The authors wish to acknowledge the input of Coillte in allowing access to state forestry for this project, and for providing logistical support and advice. A special thanks to Dr. Michael Rodgers and all at the Marine Institute for their continued help throughout this project and for supplying the orthophotography.

9

\section{(1)}

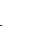

82

83

\section{4}

\section{5}

\section{6}




\section{References}

Allott, N., McGinnity, P., O’Hea, B., 2005. Factors influencing the downstream treansport of sediment in the Lough Feeagh catchment, Burrishoole, Co.Mayo, Ireland. Freshwater Forum. 23, 126-138.

APHA, 1998. Standard methods for examination of water and wastewater. $19^{\text {th }}$ ed. American Public Health Association, Washington.

Aust, W.M., Blinn, C.R., 2004. Forestry best management practices for timber harvesting and site preparation in the eastern United States: An overview of water quality and productivity research during the past 20 years (1982-2002). Wat. Air Soil Poll. 4, 536.

Bacon, P., 2003. Forestry: A growth industry in Ireland. (Assessed $17^{\text {th }}$ February 2011) http://www.coillte.ie/fileadmin/templates/pdfs/BaconReport.pdf.

Bain, C.G., Bonn, A., Stoneman, R., Chapman, S., Coupar, A., Evans, M., Gearey, B., Howat, M., Joosten, H., Keenleyside, C., Labadz, J., Lindsay, R., Littlewood, N., Lunt, P., Miller, C.J., Moxey, A., Orr, H., Reed, M., Smith, P., Swales, V., Thompson, D.B.A., Thompson, P.S., Van de Noort, R., Wilson, J.D., Worrall, F., 2011. IUCN UK commission of inquiry on peatlands. (Assessed $11^{\text {th }}$ February 2012) http://www.iucnuk-peatlandprogramme.org/commission/

Bowman, J., 2009. New Water Framework Directive environmental quality standards and biological and hydromorphological classification systems for surface waters in Ireland. Biol. and Environ: Proc. Roy. Ir. Acad. 109B, 247-60.

Broadmeadow, S., Nisbet, T.R., 2004. The effects of riparian forest management on the freshwater environment: A literature review of best management practice. Hydrol. Earth Sys. Sci. 8, 286-305. 
Carling, P. A., Irvine, B. J., Hill, A., Wood, M., 2001. Reducing sediment inputs to Scottish streams: A review of the efficacy of soil conservation practices in upland forestry. Sci. Tot. Environ. 265: 209-227.

Coillte, 2012. Retrieved 21 May 2012, from http://www.coillte.ie/coillteforest/responsible forest management and certification/c ertification introduction/.

Coillte, 2011. 2011 - 2015 W3 District Strategic Plan. In, Connemara \& Mayo. (Assessed 20 $0^{\text {th }}$ May 2012) http://www.coillte.ie/fileadmin/templates/pdfs/dsp/W3-2011-2015-DSPnew2.pdf

Cummins, T., Farrell, E.P., 2003. Biogeochemical impacts of clearfelling and reforestation on blanket peatland streams I. phosphorus. For. Ecol. Man. 180, 545-555.

Daniel, T.C., Sharpley, A.N., Lemunyon, J.L., USDA, A., USDA, N., 1998. Agricultural phosphorus and eutrophication: a symposium overview. J. Environ. Qual. 27, 251-257.

EEA. 2004. Revision of the assessment of forest creation and afforestation in Ireland. Forest

$$
\text { Network } \quad \text { Newsletter. } \quad \text { (Assessed } \quad 21^{\text {st }} \quad \text { April }
$$
http://www.woodlandleague.org/documents/ForestryInIreland/Appendices/4_Irelands CommitmentsToSFM/documents/Ref20_FNN150.pdf

Elrashidi, M.A., 2011. Selection of an appropriate phosphorus test for Soils. (Assessed $12^{\text {th }}$ June 2011) ftp://ftp-fc.sc.egov.usda.gov/NSSC/Analytical_Soils/phosphor.pdf.

EPA, 2005. Phosphorus regulations national implementation report. (Assessed $14^{\text {th }}$ May 2011) http://www.epa.ie/downloads/pubs/water/phosphorus/EPA_phosphorus_report_2005.p df.

Farmer, R.A., Nisbet, T.R., 2004. An overview of forest management and change with respect to environmental protection in the UK. Hydrol. Earth Sys. Sci. 8, 279-285.

Forest Research, 2009. Guidance on site selection for brash removal. (Assessed $22^{\text {nd }}$ October 2011)http://www.biomassenergycentre.org.uk/pls/portal/docs/PAGE/BEC_TECHNIC AL/BEST\%20PRACTICE/BRASH_RESIDUE_PROTOCOL-1.PDF. 
Forest Service, 2000. Forest and water quality guidelines. (Assessed $14^{\text {th }}$ November 2011) http://www.agriculture.gov.ie/media/migration/forestry/publications/water_quality.pdf

Frost, I., Rydin, H., 1997. Effects of Competition, Grazing and Cotyledon Nutrient Supply on Growth of Quercus robur Seedlings. Oikos. 79, 53-58.

Gerasimov, Y. and Katarov V., 2010. Effect of bogie track and slash reinforcement on sinkage and soil compaction in soft terrains. Croat. J. For. Eng. 31, 35-45.

Giesler, R., Andersson, T., Lövgren, L., Persson, P., 2005. Phosphate sorption in aluminumand iron-rich humus soils. Soil Sci. Soc. Am. J. 69, 77-86.

Goudie, A., 2006. The human impact on the natural environment: past, present and future. Sixth ed. Blackwell Sci., New Jersey.

Haygarth, P.M., Condron, L.M., Heathwaite, A.L., Turner, B.L., Harris, G.P., 2005. The phosphorus transfer continuum: Linking source to impact with an interdisciplinary and multi-scaled approach. Sci. Tot. Environ. 344, 5-14.

Haygarth, P.M., Hepworth, L., Jarvis, S.C., 1998. Forms of phosphorus transfer in hydrological pathways from soil under grazed grassland. Euro. J. Soil Sci. 49, 65-72.

Haygarth, P.M., Warwick, M.S., House, W.A., 1997. Size distribution of colloidal molybdate reactive phosphorus in river waters and soil solution. Wat. Res. 30, 439-448.

Hutton, SA., Harrison, SSC., O’Halloran, J., 2008. An evaluation of the role of forests and forest practices in the eutrophication and sedimentation of receiving waters. (Accessed $7^{\text {th }}$ May 2012) http://www.wfdireland.ie/docs/22_ForestAndWater/Forest\%20and\%20water\%20Eutro phication_Sedimentation\%20Literature\%20review\%20.pdf

Hyvönen, R., Olsson, B.A., Lundkvist, H., Staaf, H., 2000. Decomposition and nutrient release from Picea abies (L.) Karst. and Pinus sylvestris L. logging residues. For. Ecol. Man. 126, 97-112.

Joosten, H., Clarke, D., 2002. Wise use of mires and peatlands. A framework for decisionmaking. (Assessed $\quad 9^{\text {th }} \quad$ February 2012). $\quad$ http://www.gret- 

perg.ulaval.ca/fileadmin/fichiers/fichiersGRET/pdf/Doc generale/WUMP Wise Use of_Mires_and_Peatlands_book.pdf

Kominoski, J. S., S. LarraÑAga, Richardson, John S., 2012. Invertebrate feeding and emergence timing vary among streams along a gradient of riparian forest composition. Freshwat. Biol. doi: 10.1111/j.1365-2427.2012.02740.x

Luke, S.H., Luckai, N.J., Burke, J.M., Prepas, E.E., 2007. Riparian areas in the Canadian boreal forest and linkages with water quality in streams. Environ. Rev. 15, 79-97.

Long, M., Jennings, P., 2006. Analysis of the peat slide at Pollatomish, County Mayo, Ireland. Landslides. 3, 51-61.

Macrae, M.L., Redding, T.E., Creed, I.F., Bell, W.R., Devito, K.J., 2005. Soil, surface water and ground water phosphorus relationships in a partially harvested Boreal Plain aspen catchment. For. Ecol. Man. 206, 315-329.

McConnell, B. and Gatley, S. 2006. Bedrock Geology of Ireland. Derived from the Geological Survey of Ireland 1:100,000 Bedrock map series and the geological survey of Northern Ireland 1:250,000 Geological Map of Northern Ireland. (Assessed $10^{\text {th }}$ February 2012). http://www.gsi.ie/Programmes/Bedrock/Projects/GSI+publishes+All+Ireland+bedrock + map.htm

Müller, M., 2000. Hydro-geographical studies in the Burrishoole catchment, Newport, Co. Mayo, Ireland: effect of afforestation on the run-off regime of small mountain spate river catchments. SIL. 27, 1146-8.

National Forest Inventory, 2007. National Forest Inventory Republic of Ireland - Results. (Assessed 28 $8^{\text {th }}$ May 2011). http://www.agriculture.gov.ie/media/migration/forestry/nationalforestinventory/nation alforestinventorypublications/4330NFIResults.pdf 
O’Driscoll, C., Rodgers, M., O’Connor, M., Asam, Z.-u.-Z., de Eyto, E., Poole, R., Xiao, L., 2011. A potential solution to mitigate phosphorus release following clearfelling in peatland forest catchments. Wat. Air Soil Poll. 221, 1-11.

Ormerod, S.J., Rundle, S.D., Lloyd, E.C., Douglas, A.A., 1993. The influence of riparian management on the habitat structure and macroinvertebrate communities of upland streams draining plantation forests. J. Appl. Ecol. 30, 13-24.

Owende, P.M.O., Lyons, J., Haarlaa, R., Peltola, A., Spinelli, R., Molano, J., Ward, S.M., 2002. Operations protocol for eco-efficient wood harvesting on sensitive sites. (Assessed $6^{\text {th }}$ January 2012). http://www.ucd.ie/foresteng/html/ecowood/op.pdf

Parkyn, S.M., Davies-Colley, R.J., Cooper, A.B., Stroud, M.J., 2005. Predictions of stream nutrient and sediment yield changes following restoration of forested riparian buffers. Ecol. Eng. 24, 551-558.

Regan, J.T., Rodgers, M., Healy, M.G., Kirwan, L., Fenton, O., 2010. Determining phosphorus and sediment release rates from five irish tillage soils. J. Environ. Qual. 39, 185-192.

Renou-Wilson, F., Keane, M., Farrell, E.P., 2008. Establishing oak woodland on cutaway peatlands: Effects of soil preparation and fertilization. For. Ecol. Man. 255, 728-737.

Renou, F., Scallan, Ú., Keane, M., Farrell, E.P., 2007. Early performance of native birch (Betula spp.) planted on cutaway peatlands: Influence of species, stock types and seedlings size. Euro. J. For. Res. 126, 545-554.

Rodgers, M., O'Connor, M., Healy, M.G., O'Driscoll, C., Asam, Z.-u.-Z., Nieminen, M., Poole, R., Müller, M., Xiao, L., 2010. Phosphorus release from forest harvesting on an upland blanket peat catchment. For. Ecol. Man. 260, 2241-2248.

Rodgers, M., O'Connor, M., Robinson, M., Muller, M., Poole, R., Xiao, L., 2011. Suspended solid yield from forest harvesting on upland blanket peat. Hydrol. Proc. 25, 207-216.

Ryder, L., de Eyto, E., Gormally, M., Sheehy Skeffington, M., Dillane, M., Poole, R., 2011. Riparian zone creation in established coniferous forests in Irish upland peat 
catchments: Physical, chemical and biological implications. Biol. and Environ: Proc. Roy. Ir. Acad. 111B, 1-20.

Sharpley, A.N., Daniel, T., Sims, T., Lemunyon, T., Stevens, S., Parry, R., 2003. Agricultural Phosphorus and Eutrophication. (Assessed 15 ${ }^{\text {th }}$ January 2011). http://www.ars.usda.gov/is/np/phos\&eutro2/agphoseutro2ed.pdf

Sjörs, H., 1980. Peat on Earth: Multiple Use or Conservation? Ambio. 9, 303-308.

Strahler, A.N., 1957. Quantitative analysis of watershed geomorphology. Trans. of the American Geophys. Union 38, 913-920.

Syversen, N., Borch, H., 2005. Retention of soil particle fractions and phosphorus in coldclimate buffer zones. Ecol. Eng. 25, 382-394.

Väänänen, R., Nieminen, M., Vuollekoski, M., Nousiainen, H., Sallantaus, T., Tuittila, E.S., Ilvesniemi, H., 2008. Retention of phosphorus in peatland buffer zones at six forested catchments in southern Finland. Silva Fennica. 42, 211-231.

Väänänen, R., Kenttämies, K., Nieminen, M., Ilvesniemi, H., 2007. Phosphorus retention properties of forest humus layer in buffer zones and clear-cut areas in southern Finland. Boreal Environ. Res. 12, 601-609.

Väänänen, R., Nieminen, M., Vuollekoski, M., Ilvesniemi, H., 2006. Retention of phosphorus in soil and vegetation of a buffer zone area during snowmelt peak flow in southern Finland. Water, Air, and Soil Pollution. 177, 103-118.

Walker, B. H., 1992. Biodiversity and Ecological Redundancy. Conserv. Bio._ 6, 18-23. 
Figure 1. Location of Altaconey Riparian Buffer Zone (RBZ) with all standpipes (20,

74150 and $100 \mathrm{~cm}$ depths), stream sampling locations upstream and downstream of buffer, 742 and rain gauge.

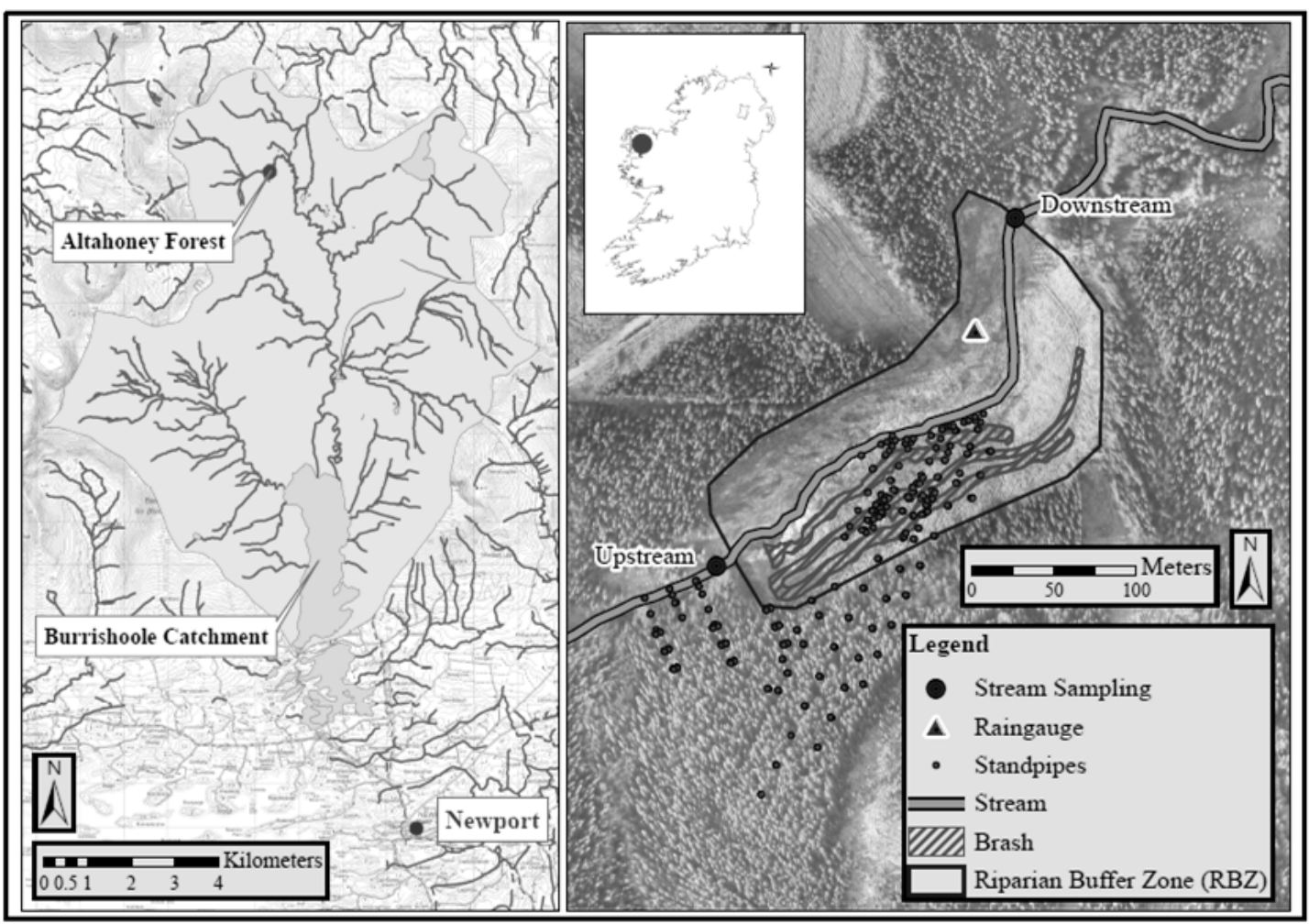


$754 \quad$ Figure 2. Sapling plot planting locations

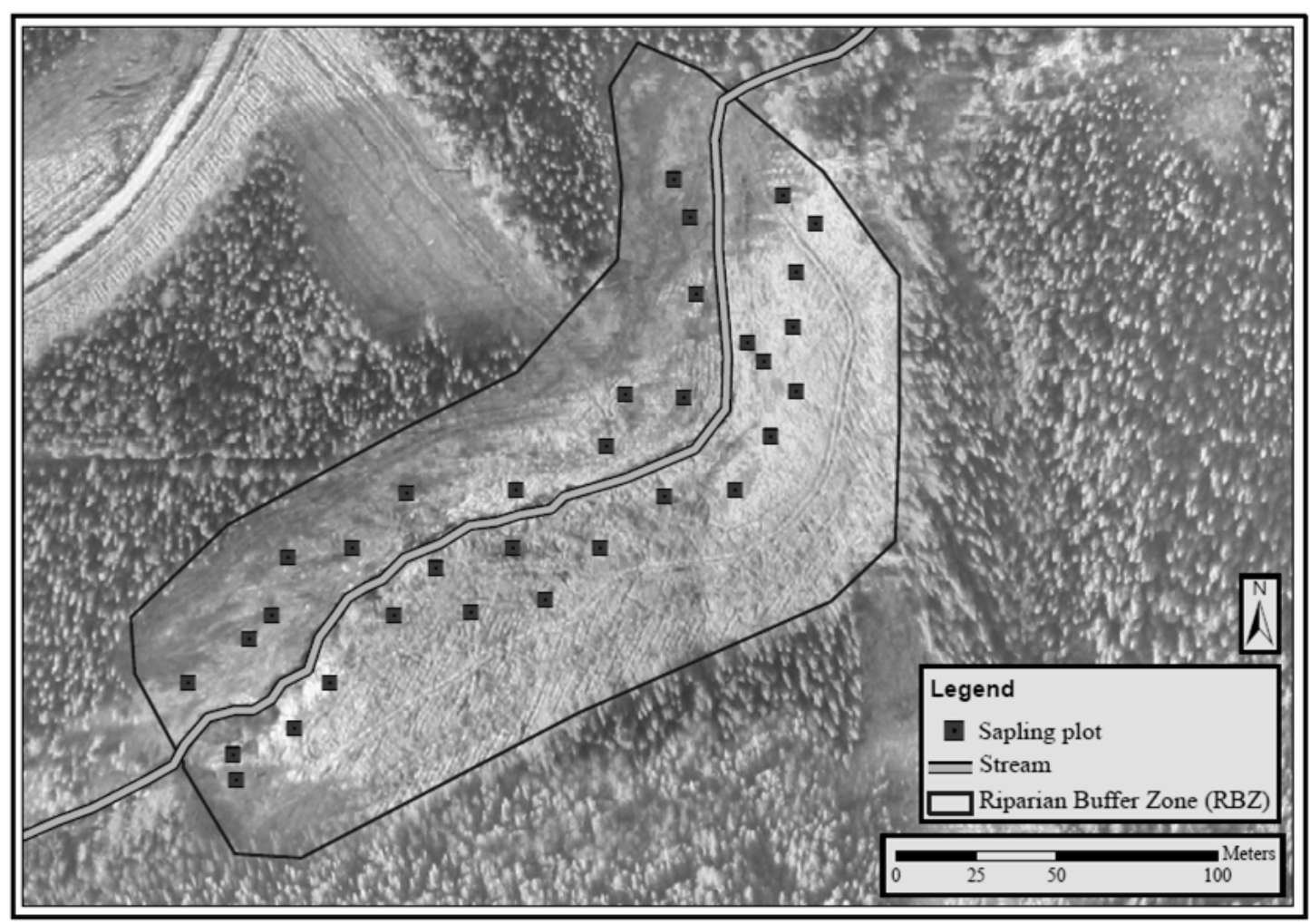


Figure 3. Percentage average increase in height of surviving saplings on site from April 2007 to August 2011 per tree species. Error bars indicate standard error.

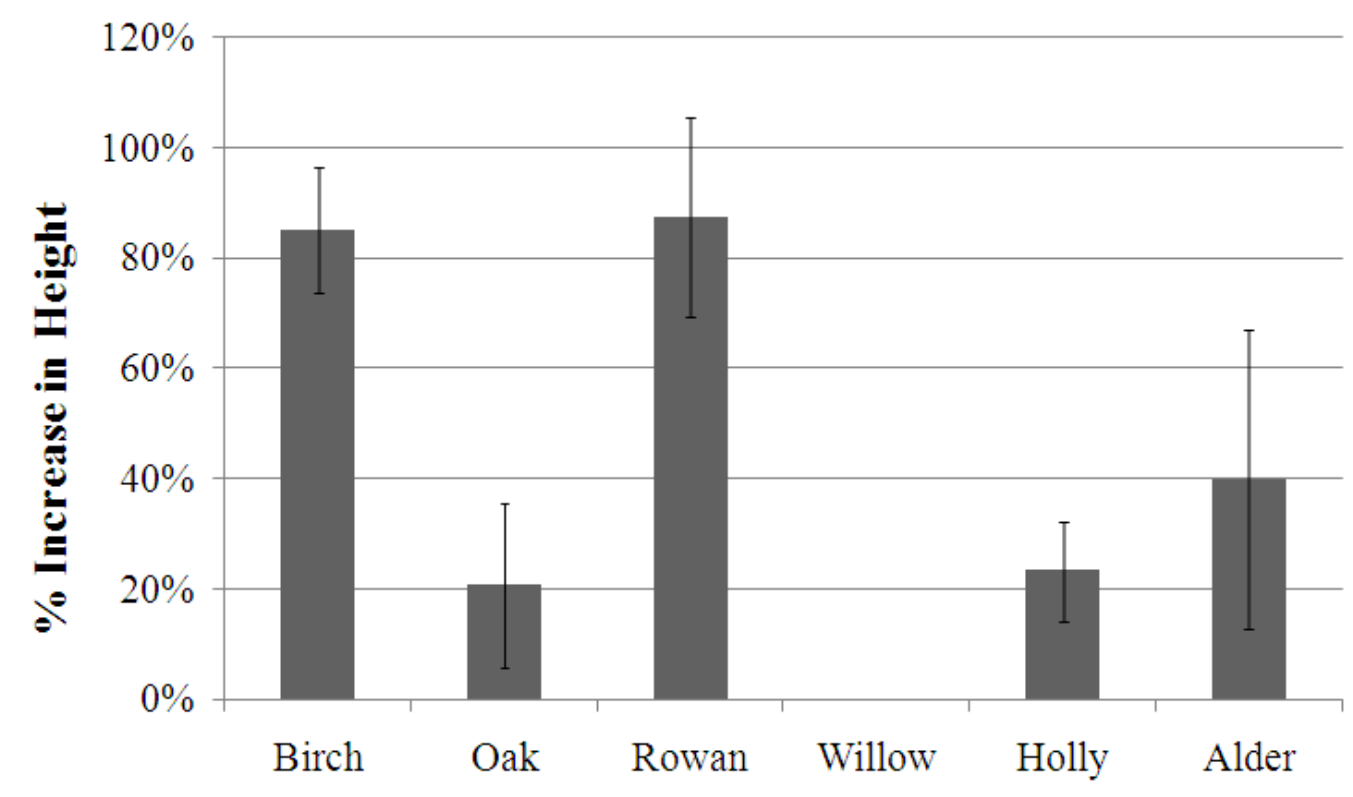


783

784

785

786

787

788

789

790

791

792

793

794

795

796

Figure 4. Average dissolved reactive phosphorus (DRP) concentration from $20 \mathrm{~cm}, 50$ $\mathrm{cm}$ and $100 \mathrm{~cm}$ depths below the ground surface measured over a 12 month period (April 2010 - April 2011) and expressed as $\mu g \mathrm{~L}^{-1}$

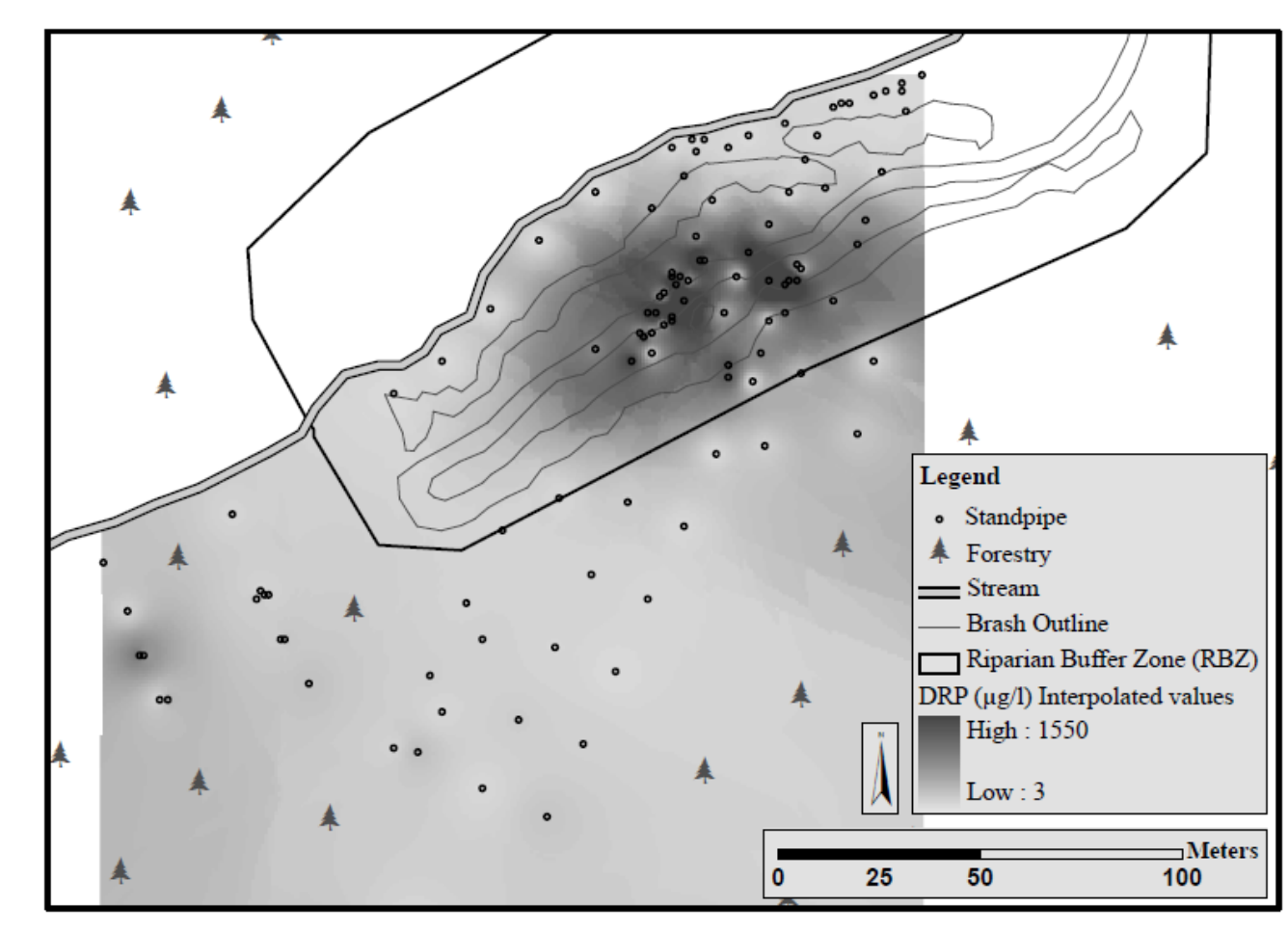

(1)

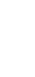


797

798

799

800

801

802

803

804

805

806

807

808 809

810

811 812 04

\section{8} 10 11

Figure 5. Dissolved reactive phosphorus (DRP) concentration measured over a 12 month period (April 2010 - April 2011) and expressed as $\mu g \mathrm{~L}^{-1}$ in stream water upstream and downstream of the RBZ.

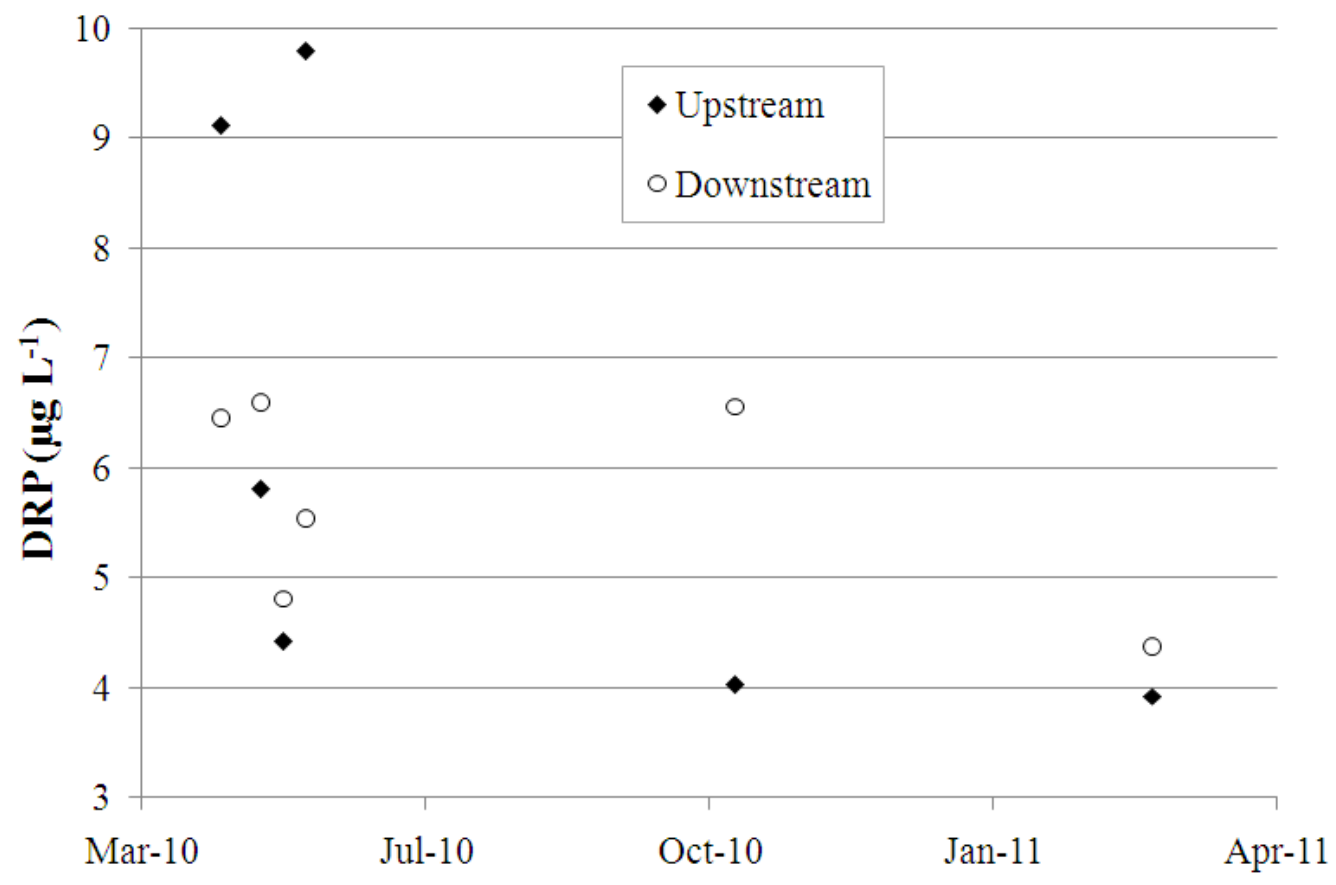

\section{2} 3 05 6 7 
813

814

815

816

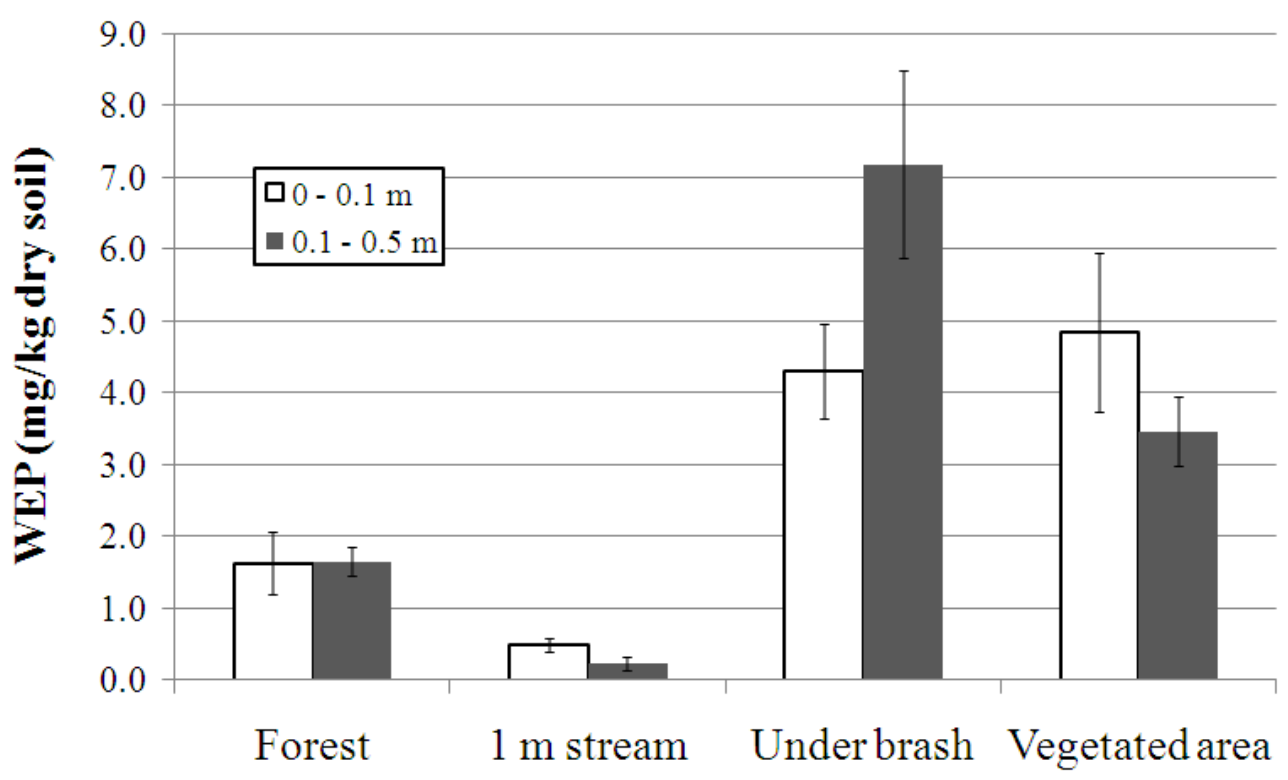

817

Figure 6. Water extractable Phosphorus (WEP) concentration (mg kg-1 dry soil) in riparian buffer zone ( $1 \mathrm{~m}$ from the stream, under brash and vegetated area) and forest at $0-0.1 \mathrm{~m}$ and $0.1-0.5 \mathrm{~m}$ depths. Error bars indicate standard deviation.

818

819

820

821

822

823

824

825

826

827

828 
Figure 7: Phosphorus (P) adsorption isotherms in riparian buffer zone and forest by

831 weight $\left(\mathrm{mg} \mathrm{g}^{-1}\right)$ on left and by volume $\left(\mathrm{mg} \mathrm{cm}^{-3}\right)$ on right at $0-0.15 \mathrm{~m}$ (top) and 0.15 -

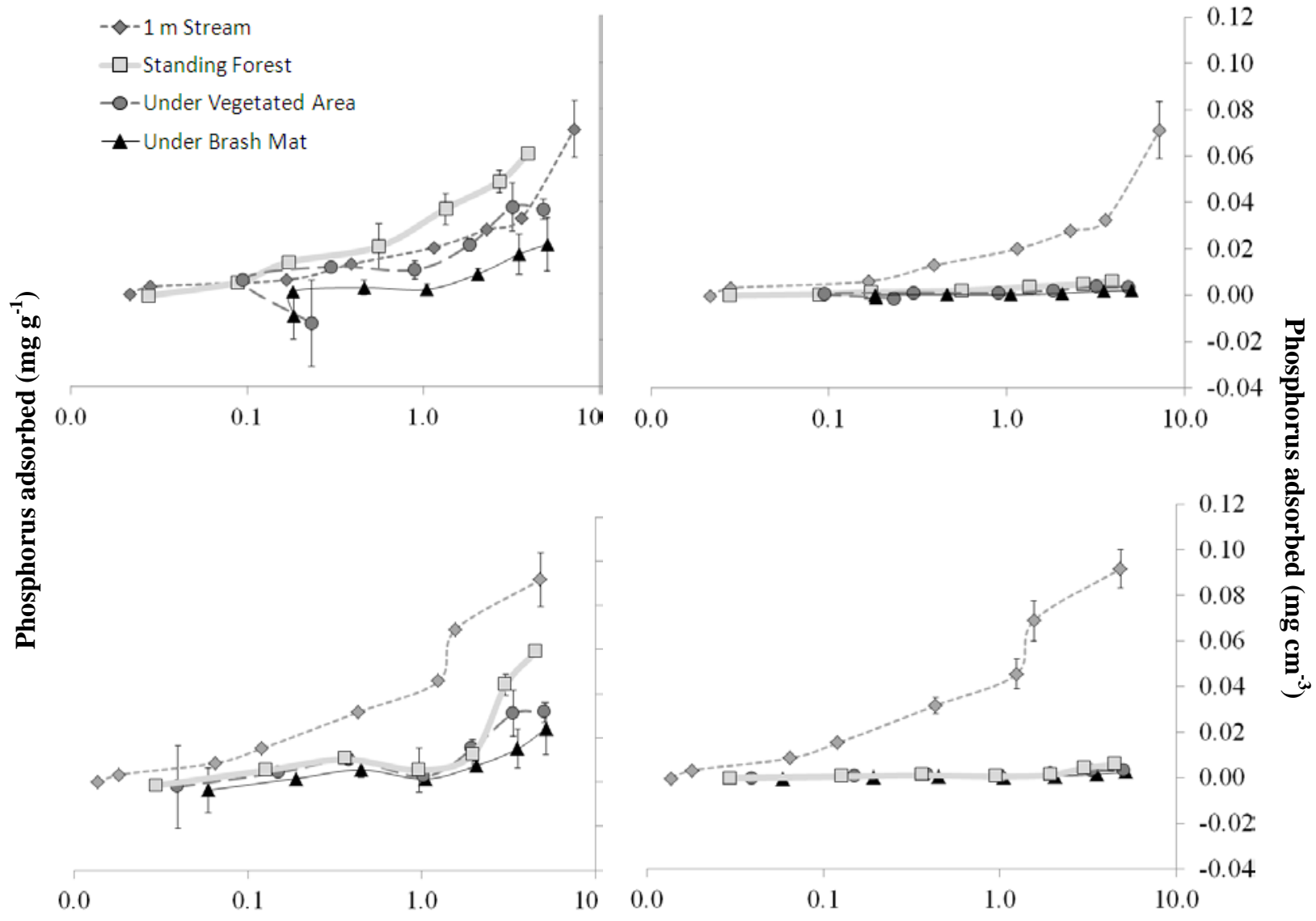

Phosphorus in equilibrium solution $\left(\mathrm{mg} \mathrm{L}^{-1}\right)$

Phosphorus in equilibrium solution ( $\mathrm{mg} \mathrm{L}^{-1}$ ) 
Figure 8: Box Plots of dissolved reactive phosphorus (DRP) (top), ammonium-N 841 ( $\left.\mathrm{NH}_{4}-\mathrm{N}\right)$ (middle) and total oxidized nitrogen (TON) (bottom) for regenerated buffer 842 area (1 $\mathrm{m}$ from the stream, under brash mats and under the vegetated area) and 843 standing forest at $20 \mathrm{~cm}, 50 \mathrm{~cm}$ and $100 \mathrm{~cm}$ depths from April 2010 - April 2011. All 844 units are $\mu g \mathrm{~L}^{-1}$.
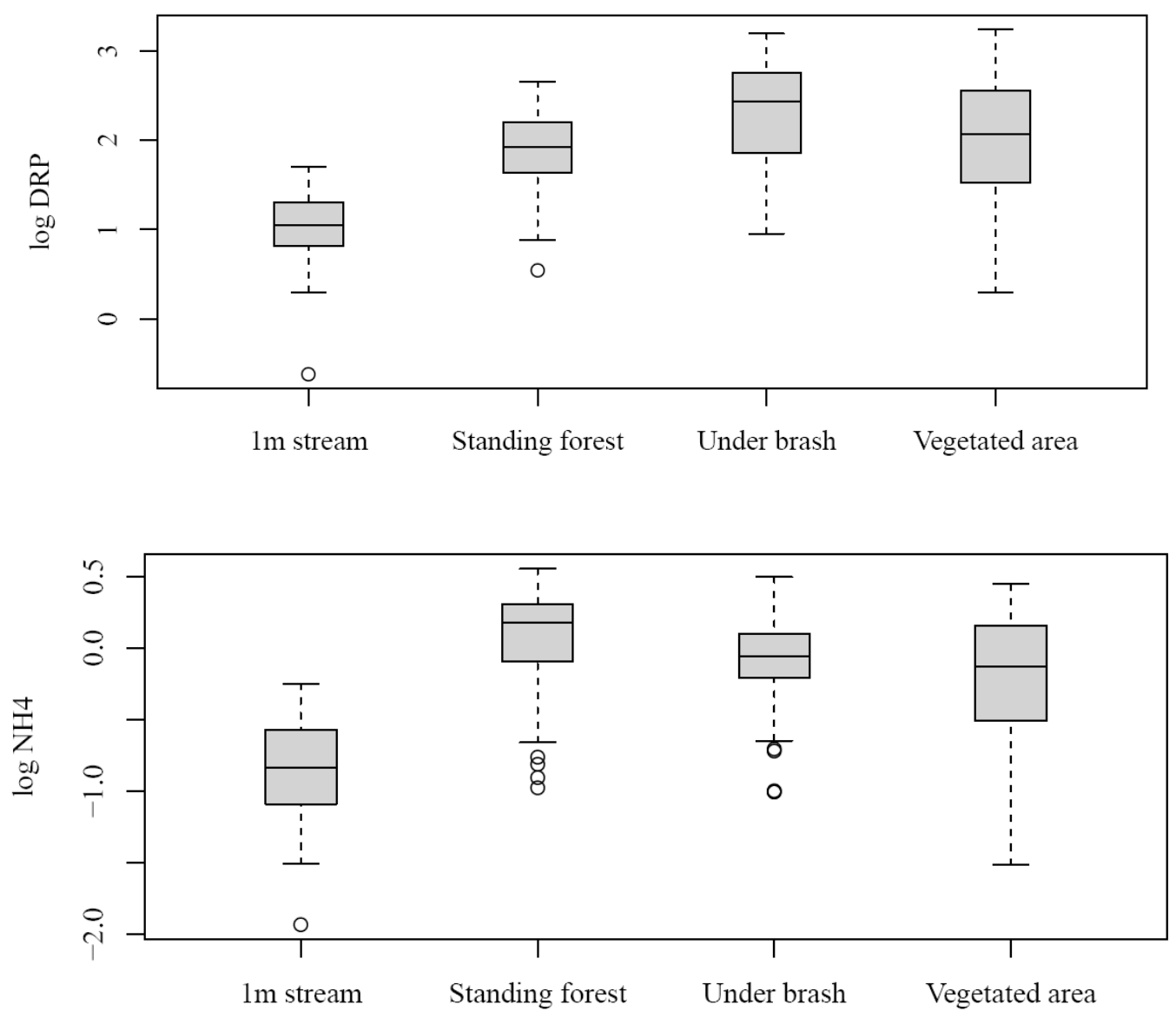


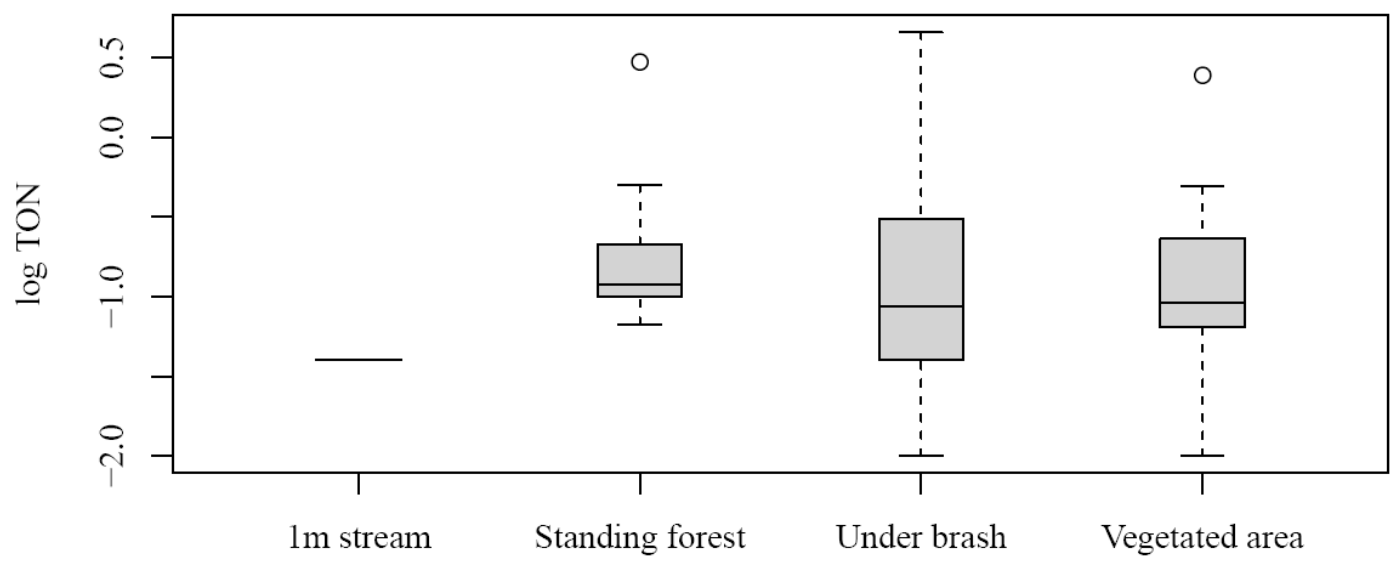

848

849

850

851

852

853

854

855

856

857

858

859

860

861

862

863

864

865 
866

867

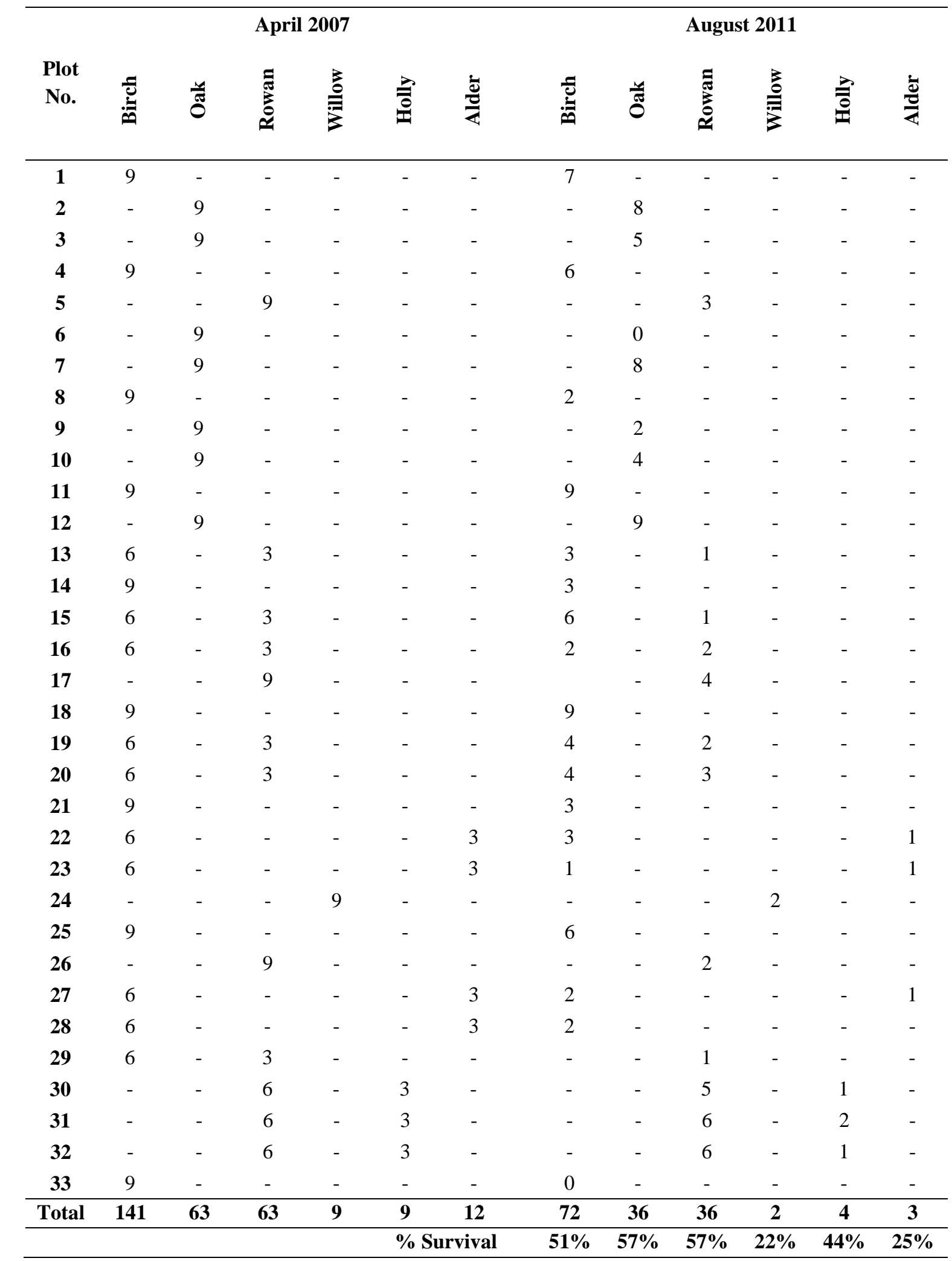

Table 1: Description of the location and composition of the sapling planting regime in April 2007, post clearfelling and surviving trees in August 2011.

\section{April 2007}

